\title{
Interrelationship between Ectoparasites and Wild Rodents from Northeastern Buenos Aires Province, Argentina
}

\author{
Santiago $\mathrm{Nava}^{+}$, Marcela Lareschi*, Damián Voglino**
}

Centro de Estudios Parasitológicos y de Vectores, Calle 2 NN $^{\circ}$ 58, 1900 La Plata, Argentina *Conicet and Departamento de Parasitologia, ICB, UFMG, Belo Horizonte, MG, Brasil **Facultad de Ciencias Naturales y Museo, UNLP, La Plata, Argentina

Infestation parameters and indices of mites, ticks and fleas associated with wild rodents from northeastern Buenos Aires Province, Argentina, were studied. Host species similarity was also analyzed in relation to their ectoparasites. Fifty-five rodents were captured from January 2000 to March 2001. In total, 1,022 ectoparasites were collected and three ectoparasite-host associations were new records. However, this is the first study on Craneopsylla minerva wolffhuegeli infesting parameters. Ectoparasite total mean abundance and total prevalence were higher in Holochilus brasiliensis $(M A=47.7 ; P=100 \%)$ and Scapteromys aquaticus $(M A=25.4 ; P=95.4 \%)$, meanwhile specific richness and diversity were higher in Oligoryzomys flavescens $(S=6 ; H=1.3)$ and Akodon azarae $(S=4$; $H=1.0$ ). On the other hand, the only individual of Calomys laucha was not parasited. S. aquaticus-H. brasiliensis, which preferred similar microhabitats, shared the same ectoparasite species $($ Css $=100)$. Whereas, A. azarae, which was mostly associated with grassland, showed the highest difference with the other hosts (Css $<0.4)$. Considering every ectoparasite species, H. brasiliensis showed the highest mean abundance, prevalence and preference. The results suggest that the particular characteristics of this rodent would give it better possibilities not only of being infested by ectoparasites, but also of transmitting them to its progeny.

Key words: ectoparasites - fleas - mites - ticks - wild rodents - Argentina

The Order Rodentia comprises the most abundant and diverse mammals in South America (Reig 1981). However, 92 of the 372 species of mammals known in Argentina are sigmodontinae rodents (Galliari et al. 1996). Particularly in Buenos Aires Province, an important number of wild rodent species have been recorded from the marginal forest along La Plata and Paraná rivers (Massoia 1961, Olrog \& Lucero 1981, Redford \& Eisenberg 1992, Sánchez López 1998). Like most of the eutherian mammals, rodents are associated with ectoparasites belonging to different species of Acari and Insecta. In Argentina there are relatively few records of ectoparasites of wild rodents where mites, ticks and fleas are studied simultaneously (Castro et al. 1987, Lareschi 1996, 2000, Liljesthröm \& Lareschi 2002). Early researches were primarily lists of hosts and their ectoparasite species and taxonomic studies, but little has been published about the ectoparasite infestation parameters. In the past ten years, several studies have quantified the host-ectoparasite relationship and contribute important information on this subject. The most relevant researches were obtained from Punta Lara (Lareschi 1996, 2000) and Berisso (Liljesthröm \& Lareschi 2002) in Buenos Aires Province and Villa Elisa in Entre Ríos Prov-

Supported partially by La Plata National University, Argentina.

${ }^{+}$Corresponding author. Fax: +54-221-423-2327. E-mail: snava@netverk.com.ar

Received 8 July 2002

Accepted 6 November 2002 ince (Abba et al. 2001). In the present study infestation parameters of mites, ticks and fleas associated with wild rodents from northeastern Buenos Aires Province, Argentina, are analyzed. Host species similarity is also studied in relation to their ectoparasites.

\section{MATERIALS AND METHODS}

The study area is located in Ramallo ( $33^{\circ} 32^{\prime} \mathrm{S}$; $\left.59^{\circ} 52^{\prime} \mathrm{W}\right)$ and San Nicolás cities (3320'S; $\left.60^{\circ} 13^{\prime} \mathrm{W}\right)$, on the coastal fringe of the Paraná River in Buenos Aires Province, Argentina. It is situated in an ecotonal area between Guianan-Brazilian and Patagonian zoogeographic Neotropical subregions (Ringuelet 1961), where the climate is temperate humid-mesothermal, with an undefined rainy season and scarce incidence of freezing conditions (Cabrera \& Dawson 1944, Dascanio et al. 1994). In this area there are xeromophic woods with trees and shrubs and along the coast there is riverine marshland where rushes are dominant.

The rodents were captured from January 2000 to March 2001 using a rectangular grid with 100 trap stations $(10 \mathrm{X}$ 10) $10 \mathrm{~m}$ apart (Cueto et al. 1995) and a Kuns-Massoia live-trap-type $(7.5 \mathrm{~cm}$ in width, $15 \mathrm{~cm}$ in length and $8 \mathrm{~cm}$ in height) was placed at each station. Traps were baited with bread and eatable oil. Captures were realized in accordance with regulations and policies from Dirección de Administración y Difusión Conservacionista del Ministerio de Asuntos Agrarios de la Provincia de Buenos Aires, Argentina. Then, the rodents were carried to the laboratory where they were killed by inhalation of a lethal dose of sulfuric ether and preserved in individual nylon bags with $10 \%$ formol. The ectoparasites were recovered by hand from the host coat with magnifying lens and preserved in $70 \%$ ethanol. They were mounted on permanent slides following the conventional techniques for each 
group. Mites were identified following Furman (1972) and Strandtmann and Wharton (1958) keys and descriptions, ticks following Boero (1957) and fleas following Hopkins and Rothschild (1956), Johnson (1957), Smit (1987) and Linardi and Guimarães (2000). Representative specimens of host and ectoparasite species were housed in the Departments of Vertebrate Zoology and Entomology, La Plata Museum, Argentina, respectively. Rodents were identified by investigators from the above mentioned museum on the basis of their morphological characteristics. For every host species the following indices and parameters were calculated: ectoparasite specific richness ( $\mathrm{S}=$ number of species), Shannon specific diversity index $[\mathrm{H}=-\Sigma$ (pi ln pi)], mean abundance (MA = total number of individuals of a particular parasite species in a sample of a particular host species/total number of hosts of that species, including both infected and non-infected hosts) and prevalence $[\mathrm{P}=$ (number of hosts infected with one or more individuals of a particular parasite species/the number of hosts examined for that parasite species) $x$ 100] (Begon et al. 1988, Bush et al. 1997). Host preference was studied by means of the specific index (SI = number of ectoparasites of a particular species in a particular host species X 100/sum of number of ectoparasites of that species in all host species) (Marshall 1981). The similarity between host species, considering ectoparasite presence/ absence, was analyzed by using Css Sorensen index $(\mathrm{Css}=2 \mathrm{C} / \mathrm{S} 1+\mathrm{S} 2)$ (Morales \& Pino 1987).

\section{RESULTS}

Fifty-five wild rodents were captured (Muridae, Sigmodontinae). Scapteromys aquaticus Thomas, 1920 was the most abundant species (40\%) followed by Akodon azarae (Fischer, 1829) (30.9\%), Oligoryzomys flavescens (Waterhouse, 1837) (14.5\%), Holochilus brasiliensis (Desmarest, 1819) (12.7\%) and Calomys laucha (Fischer, 1814) (1.8\%). In total 1,022 ectoparasites belonging to the following species were identified: Acari, Parasitiformes, Laelapidae: Laelaps manguinhosi Fonseca, 1935, Laelaps paulistanensis Fonseca, 1935,
Androlaelaps fahrenholzi (Berlese, 1911), Androlaelaps rotundus (Fonseca, 1935), Mysolaelaps microspinosus Fonseca, 1935 and Gigantolaelaps mattogrossensis (Fonseca, 1939); Ixodidae: Ixodes loricatus Neumann, 1899; Insecta, Siphonaptera, Stephanocircidae Craneopsylla minerva wolffhuegeli (Rothschild, 1909); Rhopalopsyllidae: Polygenis (Neopolygenis) atopus (Jordan \& Rothschild, 1922) and Polygenis (Polygenis) rimatus (Jordan, 1932) (Table I).

The only C. laucha individual captured was not infested. Comparing presence/absence of ectoparasite species on every host species, S. aquaticus and $H$. brasiliensis showed the highest similarity (Css $=100 \%)$, meanwhile A. azarae, in comparison with every remaining host, showed the lowest values (vs both $S$. aquaticus and $H$. brasiliensis $\mathrm{Css}=44.4 \%$; vs $O$. flavescens $\mathrm{Css}=$ $20 \%$ ). However, S. aquaticus-O. flavescens and $H$. brasiliensis-O. flavescens (both pairs Css $=73 \%$ ) exhibited intermediate values. O. flavescens $(\mathrm{S}=6 ; \mathrm{H}=1.3)$ and A. azarae $(\mathrm{S}=4 ; \mathrm{H}=1.1)$ showed the highest ectoparasite diversity index, while $S$. aquaticus exhibited the lowest one $(\mathrm{H}=0.6 ; \mathrm{S}=5)$ and $H$. brasiliensis showed intermediate values $(\mathrm{S}=5 ; \mathrm{H}=0.8)$. Mean abundance and prevalence of every ectoparasite in every host species are showed in Table II. H. brasiliensis and S. aquaticus exhibited the highest total mean abundance and total prevalence. L. manguinhosi showed the highest values of these both parameters on $S$. aquaticus and $H$. brasiliensis, $A$. rotundus on $A$. azarae and $M$. microspinosus on $O$. flavescens. Five of the ten species recorded in this study were associated with two or more host species and they all preferred $H$. brasiliensis, although the values of every ectoparasite specific index were also high on S. aquaticus, except for G. mattogrossensis (Table III).

\section{DISCUSSION}

Most of the host-ectoparasite associations recorded in this study have already been mentioned, except for $L$. manguinhosi-A. azarae, C. m. wolffhuegeli-S. aquaticus and $C$. m. wolffuegeli-H. brasiliensis which are recorded

TABLE I

Number and species of ectoparasites associated with wild rodents from northeastern Buenos Aires Province, Argentina

\begin{tabular}{|c|c|c|c|c|c|}
\hline \multirow[b]{3}{*}{ Ectoparasites } & \multicolumn{4}{|c|}{ Examined rodents } & \multirow[b]{2}{*}{ Total } \\
\hline & $\begin{array}{c}\text { Scapteromys } \\
\text { aquaticus }\end{array}$ & $\begin{array}{l}\text { Akodon } \\
\text { azarae }\end{array}$ & $\begin{array}{l}\text { Oligoryzomys } \\
\text { flavescens }\end{array}$ & $\begin{array}{l}\text { Holochilus } \\
\text { brasiliensis }\end{array}$ & \\
\hline & $\mathrm{n}=22$ & $\mathrm{n}=17$ & $\mathrm{n}=8$ & $\mathrm{n}=7$ & $\mathrm{n}=55$ \\
\hline Laelaps manguinhosi & 477 & 1 & 2 & 254 & 734 \\
\hline L. paulistanensis & - & - & 11 & - & 11 \\
\hline Androlaelaps fahrenholzi & 38 & 13 & - & 24 & 75 \\
\hline A. rotundus & - & 51 & - & - & 51 \\
\hline Mysolaelaps micropinosus & - & - & 21 & - & 21 \\
\hline Gigantolaelaps mattogrossensis & 1 & - & 5 & 38 & 44 \\
\hline Ixodes loricatus & - & 22 & - & - & 22 \\
\hline Craneopsylla m. wolffhuegeli & 21 & - & 1 & 9 & 31 \\
\hline Polygenis (N.) atopus & 23 & - & - & 9 & 32 \\
\hline$P .(P$.$) rimatus$ & - & - & 1 & - & 1 \\
\hline Total & 560 & 88 & 40 & 334 & 1022 \\
\hline
\end{tabular}


TABLE II

Mean abundance (MA), standard deviation (SD) and prevalence (P \%) of every ectoparasite associated with every wild rodent species from northeastern Buenos Aires Province, Argentina

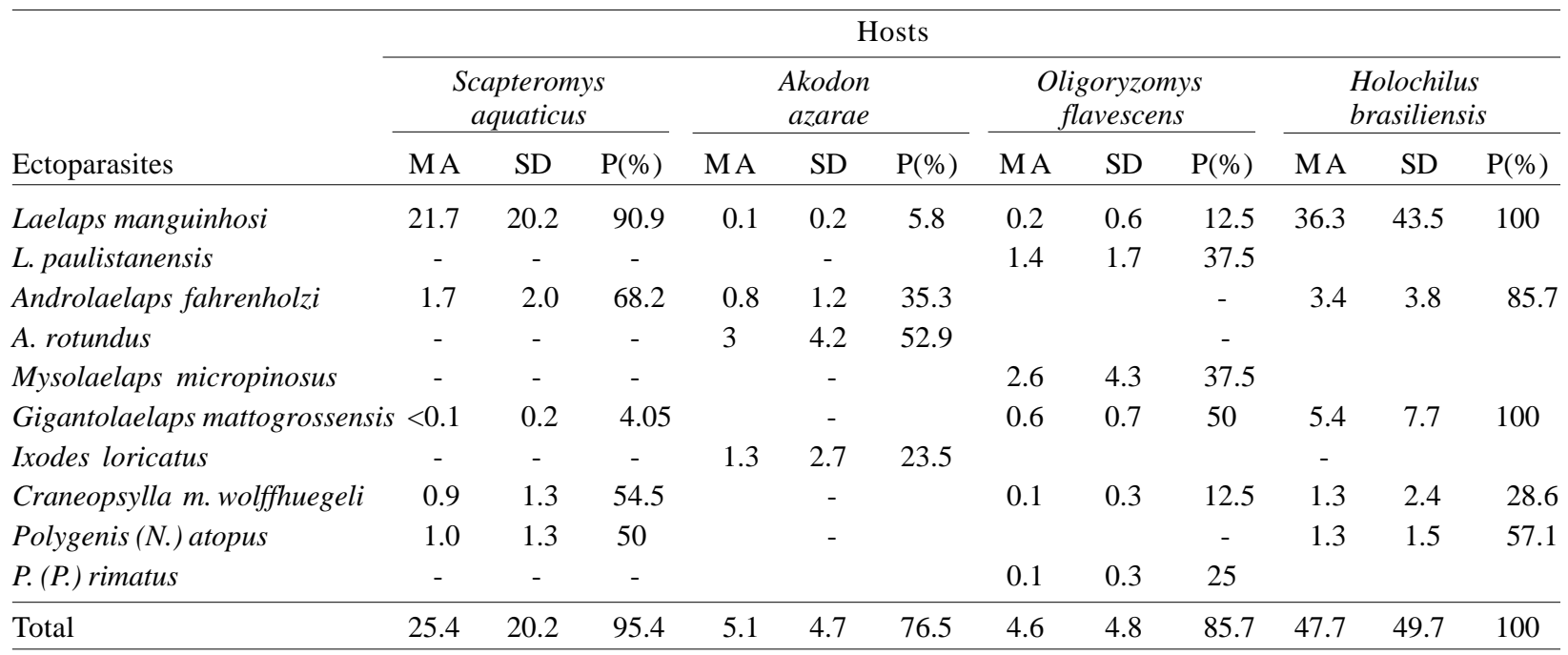

TABLE III

Host species preference (SI) for every ectoparasite species associated with wild rodents from northeastern Buenos Aires Province, Argentina

\begin{tabular}{lcccc}
\hline & \multicolumn{3}{c}{ Hosts } \\
\cline { 2 - 5 } & Scapteromys aquaticus & Akodon azarae & Oligoryzomys flavescens & Holochilus brasiliensis \\
\hline Ectoparasites & 162.5 & 0.4 & 1.9 & 272.0 \\
Laelaps manguinhosi & 127.2 & 55.9 & - & 252.2 \\
Androlaelaps fahrenholzi & 5.0 & - & 78.8 & 678.7 \\
Gigantolaelaps mattogrossensis & 169.6 & - & 23.2 & 230.3 \\
Craneopsylla m. wolffhuegeli & 173.3 & - & - & 215.0 \\
Polygenis (N.) atopus & & & & \\
\hline
\end{tabular}

for the first time in Argentina. However, the subspecies $C$. m. minerva, next to C. $m$. wolffhuegeli, has been previously mentioned infesting S. aquaticus in Delta of Paraná river and $H$. brasiliensis in Jujuy Province (Hopkins \& Rothschild 1956, Johnson 1957, Autino \& Lareschi 1998). Considering that early researches on $C$. $m$. wolffhuegeli are lists of host species and their geographical distribution, then, this is the first study on its infesting parameters.

Concerning $C$. laucha ectoparasites, although many species infesting this host have been mentioned in Buenos Aires Province, little is known about their ecological parameters, suggesting the need of further investigations on this subject. Comparing presence/absence of ectoparasites associated with every host species in this study, A. azarae showed the least similarity with every other rodent species. In contrast with the remaining rodents, which are associated with aquatic microhabitats, $A$. azarae is mostly associated with grassland, where seeds are dominant (Bonaventura et al. 1991). However, the remaining host rodents which have similar ecological and ethologi- cal characteristics, showed higher similarities in relation to their ectoparasite species and particularly $H$. brasiliensis and S. aquaticus, the most semiaquatic rodents (Massoia \& Fornes 1964, Massoia 1976), showed the same five ectoparasite species, although all of them preferred the first host species. Not only considering that some developmental stages of ticks and fleas take place in the soil or host nest, but that also mites are sometimes collected there, the results obtained show that the usage of similar microhabitats would provide the hosts with better possibilities of sharing the same ectoparasite species. Prior studies on ectoparasites of wild rodents from Punta Lara Buenos Aires Province, Argentina, also agree with these results (Lareschi 1996).

Comparing the index and infestation parameter values in every host species, the great abundance of $L$. manguinhosi on $S$. aquaticus and $H$. brasiliensis influenced their ectoparasite specific diversity index which was lower than that in the remaining hosts; similar results have been obtained on S. aquaticus from Punta Lara (Lareschi 2000). However, H. brasiliensis showed the 
highest ectoparasite mean abundance, prevalence and preference. The low abundance of this rodent recorded in this study would be in relation to the difficulty for capturing individuals of this species principally because of the small size of the traps used. Besides, in previous studies on this rodent from nearby localities, Massoia (1976) has already noticed the above mentioned difficulty. Then, a low number of captured individuals does not always suggest a low abundance in the community. H. brasiliensis is morphologically, ecologically and ethologically well adapted to aquatic environments and principally during floods, individuals may be displaced along rivers and streams and may colonize new habitats. This rodent inhabits swamps, grasslands and other moist, unforested areas from the coastal plains of Venezuela west into the Guaianan lowlands, thence into suitable habitats in Brazil, Uruguay, Paraguay, the Amazonian basin in Peru and Bolivia, the Paraguay river basin in Bolivia, and in Argentina the Paraná river basin until Buenos Aires Province. (Hershkovitz 1955, Massoia 1976). Like other wild rodents, under certain conditions and at certain times, individuals multiply rapidly and become plagues locally known as "ratadas" (Hershkovitz 1955). In Northern Argentina, Llanos (1944 in Hershkovitz 1955) reported an Holochilus species "ratada" which indicate a natural cyclic increase of native populations. Since rodent captures were carried out during a very important flood and $H$. brasiliensis "ratada" in Buenos Aires and nearby Argentinean provinces (Santa Fe and Entre Ríos) (Polop 2001), the results obtained would be related to these events. Then during the present study, the larger $H$. brasiliensis home range in comparison with the remaining host species, would give it better possibilities of being infested by ectoparasites as an alternative host. However, the "ratadas" would also benefit the ectoparasite transmission to its progeny, principally concerning some laelapid species whose population fluctuations follow the dynamics of the host populations (Lundqvist 1985). Finally, as ticks, mites and fleas are among the most important vectors of pathogens that cause diseases in human and domestic and wild animals (Autino \& Lareschi 1998, Lareschi \& Mauri 1998), the results obtained suggest the need of further studies on this subject in order to contribute to a better understanding of the $H$. brasiliensis-ectoparasites relationship.

\section{ACKNOWLEDGMENTS}

To Laura Gorostordoy for the critical revision of the English and to UFJ Pardiñas (FCNyM, Argentina) for the identification of the rodents. To PM Linardi (ICB/UFMG, Brazil) for his assistance with the identification of $P$. (P.) rimatus.

\section{REFERENCES}

Abba A, Udrizar Sauthier DE, Bender JB, Lareschi M 2001. Mites (Acari: Laelapidae) associated with sigmodontinae rodents in Entre Ríos Province, Argentina. Mem Inst Oswaldo Cruz 96: 1171-1172.

Autino A, Lareschi M 1998. Siphonaptera. In JJ Morrone, S Coscarón (eds), Biodiversidad de Artrópodos Argentinos. Una Perspectiva Biotaxonómica, Sur, La Plata, p. 279-290. Begon M, Harper JL, Towsend CR 1988. Ecología, Individuos, Poblaciones y Comunidades, Omega, Barcelona, 886 pp.

Boero JJ 1957. Las Garrapatas de la República Argentina (Aca-
rina-Ixodoidea), UBA, Buenos Aires, 113 pp.

Bonaventura SM, Piantanida MJ, Gurini L, Sanchez Lopez MI 1991. Habitat selection in population of cricetine rodents en the region Delta (Argentina). Mammalia 55: 339-354.

Bush AO, Lafferty KD, Lotz JM, Shostak AW 1997. Parasitology meets ecology on its own terms: Margolis et al. Revisited. J Parasitol 83: 575-583.

Cabrera AL, Dawson G 1944. La selva marginal de Punta Lara, en la ribera argentina del Río de la Plata. Rev Mus La Plata, Botánica 5: 267-282.

Castro D, Mauri R, Cicchino A, Mosquera S 1987. Ectoparásitos de roedores de la Provincia de Buenos Aires, Argentina (Acarina, Anoplura, Mallophaga y Suctoria). Rev Soc Ent Arg 44: 317-327.

Cueto VR, Piantanida MJ, Cagnoni M 1995. Population demography of Oxymycterus rufus (Rodentia: Cricetidae) inhabiting a patchy environment of the delta of the Paraná River, Argentina. Acta Theriologica 40: 123-130.

Dascanio LM, Barrera M, Frangi J 1994. Biomass structure and dry matter dynamics of subtropical alluvial and exotic Ligustrum forest at the Río de la Plata, Argentina. Vegetatio 115: 61-76.

Furman DP 1972. Laelapid mites (Laelapidae: Laelapinae) of Venezuela. Brigham Young Univ Sc Bull 17: 1-58.

Galliari CA, Pardiñas UFJ, Goin F 1996. Lista comentada de los mamíferos argentinos. Mastozoología Neotropical 3: 39-61.

Hershkovitz P 1955. South American marsh rats, genus Holochilus, with a summary of sigmodont rodents. Fieldiana: Zoology 37: 639-687.

Hopkins GH, Rothschild M 1956. An Illustrated Catalogue of Rothschild Collection of Fleas (Siphonaptera) in the British Museum (NH). Volume II. Cotopsyllidae, Vermipsyllidae, Stephanocircidae, Ischnopsyllidae, Hypsophthalmidae, and Xiphiopsyllidae, British Museum (Natural History), London, $445 \mathrm{pp}$.

Johnson PT 1957. A classification of the Siphonaptera of South America. Mem Entomol Soc Washington 5: 1-298.

Lareschi M 1996. Estudio preliminar de la comunidad de roedores (Rodentia: Muridae) y sus ectoparásitos (Acari, Phthiraptera y Siphonaptera) en Punta Lara (Buenos Aires). Rev Soc Entomol Argent 55: 113-120.

Lareschi M 2000. Estudio de la Fauna Ectoparásita (Acari, Phthiraptera y Siphonaptera) de Roedores Sigmodontinos (Rodentia: Muridae) de Punta Lara, Provincia de Buenos Aires, PhD Thesis, Universidad Nacional de La Plata, Argentina, $174 \mathrm{pp}$.

Lareschi M, Mauri R 1998. Dermanyssoidea. In JJ Morrone, S Coscarón (eds), Biodiversidad de Artrópodos Argentinos. Una Perspectiva Biotaxonómica, Sur, La Plata, p. 581-590.

Liljeström G, Lareschi M 2002. Estudio preliminar de la comunidad ectoparasitaria de roedores sigmodontinos en el partido de Berisso, Provincia de Buenos Aires. In Actualizaciones en Entomo-epidemiología Argentinas, CeNDIE, Ministerio de Salud y Acción Social de la Nación, Argentina.

Linardi PM, Guimarães LR 2000. Sifonápteros do Brasil, MZUSP/Fapesp, São Paulo, 291 pp.

Lundqvist L 1985. Life Tactics and Distribution of Small Mammals Ectoparasites (Anoplura, Siphonaptera and Acari) in Northernmost Fenoscandia, $\mathrm{PhD}$ Thesis, University of Lund, Sweden, $99 \mathrm{pp}$.

Marshall AG 1981. The Ecology of Ectoparasitic Insects, Academic Press, New York, 459 pp.

Massoia E 1961. Notas sobre los cricétidos de la selva marginal de Punta Lara (Mammalia, Rodentia). Public Mus Mun Cs Nat y Tradicional de Mar del Plata 1: 115-134. 
Massoia E 1976. Fauna de Agua Dulce de la República Argentina, Conicet, Argentina, 128 pp.

Massoia E, Fornes A 1964. Notas sobre el gen. Scapteromys (Rodentia: Cricetidae) I. Sistemática, distribución geográfica y rasgos etoecológicos de S. tumidus (Waterhouse). Physis 24: 279-297.

Morales G, Pino LA 1987. Parasitología Cuantitativa, Fundación Fondo Editorial, Acta Científica Venezolana, Caracas, 132 pp.

Olrog CC, Lucero MM 1981. Guía de los Mamíferos Argentinos, Ministerio de Cultura y Educación, Fundación Miguel Lillo, Tucumán, $151 \mathrm{pp}$.

Polop JJ 2001. El municipio frente al problema del control de roedores. Plagas, Ambiente y Salud III 13: 30-32.

Redford KH, Eisenberg F 1992. Mammals of the Neotropics. The Southern Cone, Vol. 2, University of Chicago Press, Chicago, $430 \mathrm{pp}$.
Reig O 1981. Teoría del origen y desarrollo de la fauna de mamíferos de América del Sur. Monografie Naturae. Mus Mun de Cs Nat "Lorenzo Scaglia"1: 1-162.

Ringuelet RA 1961. Rasgos fundamentales de la zoogeografía de la Argentina. Physis 22: 151-170.

Sánchez López MI 1998. Factores que Limitan la Abundancia de los Roedores Múridos del Delta del Paraná, PhD Thesis, UBA, Buenos Aires, 150 pp.

Smit FGAM 1987. An Illustrated Catalogue of the Rothschild Collection of Fleas (Siphonaptera) in the British Museum (Natural History) 7: Malacopsylloidea (Malacopsyllidae and Rhopalopsyllidae), Oxford University, Oxford, 380 pp.

Strandtmann RW, Wharton GW 1958. Manual of Mesostigmatid Mites, Contribution no. 4 of The Institute of The Acarology CE Yunker, 330 pp. 